Andrzej Szczepański

Państwowa Wyższa Szkoła Zawodowa im. Witelona w Legnicy

Wydziat Pedagogiki, Turystyki i Rekreacji

\title{
Oświata żydowska w powojennej Legnicy (1945-1968)
}

\begin{abstract}
Education in post-war Legnica (1945-1968)
When the war activities came to a close, first Jews started to come into town, mainly the former prisoners from Gross-Rosen concentration camp, and then the displaced rescued in the territory of the Soviet Union. The newcomers soon opened their own educational facilities and in the school year 1946/1947 in Legnica there were: a kindergarten, a foster house, a heder, a primary school with Hebrew as the language of lecture, a kibbutz and a Hebrew primary school. The educational pluralism did not last long because from the school year 1950/1951 there remained just one state-controlled Jewish school (the other facilities had been closed). The kindergarten was the only exception and although it received the status of a public institution it preserved Jewish character until mid-50s.

The subsequent years brought significant fluctuation of teachers and students as many of them left Poland in the first half of the 1950s, whereas from 1956 more newcomers arrived from the USSR. On September 1, 1959 a high-school class was launched in the local primary school.

In the 1960s the emigration of Jews from Legnica increased significantly, which resulted in smaller number of students. A breakthrough year was 1968, when, because of too small number of children (38 in total), on August 31 the Jewish high-school and primary school ceased to exist.
\end{abstract}

Keywords: Education, Jews, Legnica, National Minorities, the Recent History of Poland

Zdaniem Ewy Waszkiewicz opisującej powojenną historię skupiska żydowskiego na Dolnym Śląsku, można w niej wyróżnić trzy okresy, tj. lata 1945-1950, 1950-1957 i 1957-1958. Pierwszy związany jest z przybyciem Żydów na nowe miejsce zamieszkania i charakteryzuje się rozkwitem bujnego życia kulturalnego, społecznego i religijnego mniejszości. To czas powołania Centralnego Komitetu Żydów w Polsce (CKŻP1) i utworzenia jego wojewódzkich oraz powiatowych filii w wielu miastach Dolnego Śląska, ale

\footnotetext{
${ }^{1}$ Centralny Komitet Żydów w Polsce - organizacja polityczna reprezentująca Żydów ocalonych z Holokaustu, powstał w listopadzie 1944 r. i funkcjonował do 1950 r.
} 
także zmiany polityki władz wobec Żydów po 1948 r. wywołanej powstaniem państwa Izrael, które przyjęło prozachodni kurs polityczny. Druga połowa lat pięćdziesiątych XX w. związana jest ze stabilizacją i normalizacją życia społeczności i jej adaptacji do nowych realiów stalinowskiego państwa. Okres trzeci, obejmujący swym zasięgiem przedział między 1957 a 1968 r. wiąże się z rozpoczęciem kolejnej repatriacji przedwojennych obywateli polskich z ZSRR (w tym również Żydów) i ich przyjazdem na Dolny Śląsk. To wreszcie czas względnego spokoju w życiu mniejszości przerwany tzw. wojną sześciodniową w 1967 r. i następnie ,wydarzeniami marcowymi”"2.

Aprobując powyższą periodyzację, w artykule zastosowałem podział dwustopniowy, wyznaczając daty cezuralne na lata 1945-1950 i 1950-1968. Pierwszy etap charakteryzował się powstaniem de facto autonomicznych wobec władzy instytucji oświatowych, gdyż w owym czasie funkcjonowały zarówno szkoły powszechne objęte opieką CKŻP, jak również religijne i syjonistyczne. Drugi okres przyniósł centralizację i ujednolicenie życia społecznego mniejszości na wszystkich płaszczyznach życia, co objęło także szkolnictwo. Tym samym od 1950 r. (roku szkolnego 1949/1950) funkcjonowały upaństwowione szkoły żydowskie, zlikwidowane po 1968 r.

\section{Sytuacja Żydów w latach 1945-1950}

W pierwszych miesiącach po zakończeniu działań wojennych liczba Żydów przebywających na południowo-zachodnich terenach nowej Polski liczyła ok. 6 tysięcy osób, głównie ocalałych więźniów obozów koncentracyjnych. Jednak bardzo szybko przybywało przedstawicieli tej mniejszości z terenów Polski Centralnej. Tradycyjnie za miejsce swojego zamieszkania wybierali miasta, gdzie włączali się w wir życia gospodarczego i politycznego mieszkańców3 ${ }^{3}$ Wzmożony napływ ludności na obszary Dolnego Śląska rozpoczął się w drugiej połowie 1945 r. (we wrześniu skupisko żydowskie szacowano na ok. 10 tys., a w grudniu już na 16 tys.), a swe apogeum osiagnął w miesiącach wiosennych następnego roku, kiedy na ten teren przybyło średnio kilkanaście tysięcy emigrantów tygodniowo ${ }^{4}$. Przewidywaną liczbę 40 tys. Żydów, jaką mógł przyjać Dolny Śląsk, przekroczono już w maju, mimo to transporty trwały nadal. Szacuje się, że do lipca przyjechało tu ok. 90 tys. osób narodowości żydowskiej, umieszczanej początkowo w Dzierżoniowie, Wałbrzychu i Wrocławiu, a następnie w wielu innych miastach i miasteczkach - m.in. Legnicy, Jaworze, Chojnowie, Ząbkowicach i Przemkowie ${ }^{5}$.

Osiedlenie się nowych przybyszy oznaczało powołanie dla nich instytucji oświatowych odpowiedzialnych za edukację dzieci i młodzieży. Tym samym już we wrześniu

\footnotetext{
2 E. Waszkiewicz Powstanie, rozkwit i zanik skupiska Żydów na Dolnym Ślasku (1945-1968), w: E. Waszkiewicz (red.), Współcześni Żydzi - Polska i diaspora. Wybrane zagadnienia, Wrocław 2007, s. 16-29.

3 S. Bronsztejn, Ludność żydowska na Dolnym Ślasku po II wojnie światowej, A. Galos (red.), Śląski Kwartalnik Historyczny „Sobótka” 1991, nr 2, Warszawa-Wrocław-Kraków 1991 r., s. 263-264.

4 Ibidem, s. 264.

5 B. Szaynok, Ludność żydowska na Dolnym Ślasku 1945-1950, Wrocław 2000, s. 47-51.
} 
1945 r. powołano szkołę podstawową w Dzierżoniowie przy Wojewódzkim Komitecie Żydowskim (WKŻ) ${ }^{6}$. Pod koniec roku we Wrocławiu utworzono pierwszą żydowską szkołę powszechną z pięcioma oddziałami, podobna placówka powstała również w Wałbrzychu. Jednak dopiero od połowy następnego roku można datować bujny rozkwit szkolnictwa żydowskiego na Dolnym Śląsku, i w całym kraju, co związane było z repatriacjami z głębi ZSRR. Jeśli w czerwcu 1946 r. w województwie wrocławskim istniało 16 szkół kształcących 1280 dzieci (m.in. we Wrocławiu, Dzierżoniowie, Legnicy, Świdnicy i Chojnowie), to miesiąc później liczba placówek zwiększyła się o trzy kolejne (w Bystrzycy, Bielawie i Przemkowie), aby pod koniec sierpnia 1946 r. osiagnąć liczbę 18 z 59 nauczycielami i 1393 uczniami $^{7}$. Pod patronatem WKŻ działały we Wrocławiu: gimnazjum, szkoła plastyczna, szkoła baletowa i ciesząca się najlepszą opinią w regionie szkoła muzyczna im. Hubermana ${ }^{8}$. Jej rywalką była założona rok później, a więc w 1948 r., licząca wówczas 110 uczniów, szkoła w Wałbrzychu?

Osobne miejsce zajmowało szkolnictwo syjonistyczne $\mathrm{z}$ hebrajskim językiem wykładowym, tworzone przy terenowych oddziałach organizacji He-chaluc ${ }^{10}$. Od połowy $1946 \mathrm{r}$. utworzono w Polsce 15 placówek z 100 nauczycielami i ok. 3000 uczniami. Należy jednak pamiętać, że szkoły te skupiały w swych szeregach zdecydowanych na wyjazd do Palestyny syjonistów, dlatego po fali emigracji 1947 r. pozostało wprawdzie 14 szkół, ale z ogólną liczbą ok. tysiąca uczniów. Sześć placówek działało na Dolnym Śląsku - we Wrocławiu, Dzierżoniowie, Wałbrzychu, Legnicy, Bielawie i Świdnicy ${ }^{11}$.

Obok szkół powszechnych, działających przy komitetach żydowskich i hebrajskich objętych opieką He-chaluc, istniały także szkoły religijne przy kongregacjach wyznaniowych. Były to szkoły elementarne - ,chedery”, w których hebrajskiego, geografii Palestyny i poznawania Biblii uczyły się dzieci w wieku od 6 do 10 lat. Jedynie we Wrocławiu powstała jedna z dwóch w Polsce ,jesziwa" - średnia szkoła wyznaniowa ${ }^{12}$.

Inną formą nauki, obejmującą zarówno młodzież, jak i osoby dorosłe, było przeszkolenie do zawodu (tzw. produktywizacja) przez Organizację Rozwoju Twórczości (ORT ${ }^{13}$ ). Od 1946 r. zaczęła ona prowadzić kursy, a następnie szkoły zawodowe i organizowała

${ }^{6}$ J. Adelson, W Polsce zwanej Ludowa, w: J. Tomaszewski (red.), Najnowsze dzieje Żydów w Polsce, Warszawa 1993, s. 463.

${ }^{7}$ B. Szaynok, Ludność żydowska..., s. 73-75.

${ }^{8}$ B. Szaynok, Żydzi we Wrocławiu po II wojnie światowej, K. Gluziński (red.), Rocznik wrocławski, Wrocław 1997, s. 183.

9 S. Bronsztejn, op. cit., s. 267.

${ }^{10}$ He-chaluc (hebr. pionier) - syjonistyczny ruch, którego celem była realizacja osadnictwa w Ziemi Izraela m.in. przez przygotowanie zawodowe. Po 1944 r. na krótko odrodził się w Polsce.

11 Z. Borzymińska, Z. Żebrowski, Kultura Żydów Polskich w XX wieku, Warszawa 1993, s. 309.

${ }^{12}$ E. Waszkiewicz, Kongregacja Wyznania Mojżeszowego na Dolnym Ślasku na tle polityki wyznaniowej Polskiej Rzeczpospolitej Ludowej 1945-1968, Wrocław 1999., s. 88-89.

${ }^{13}$ ORT - Organizacja Rozwoju Twórczości - stowarzyszenie popierające rozwój rzemiosła i rolnictwa wśród Żydów przez szkolenie zawodowe. Powołany w XIX w. w Rosji szybko rozprzestrzenił sie na inne państwa., a od 1948 r. działa w Izraelu. Centrala Światowej Organizacji ORT mieści się w Genewie. 
odczyty szkoleniowe ${ }^{14}$. Początkowo były to kursy: tkacki, radiotechnika i elektronika (w Dzierżoniowie), elektrotechniczny, maszynopisania i stenograficzny (w Wałbrzychu) oraz maszynopisania i elektrotechniczny we Wrocławiu. Od 1948 r. ORT prowadziła 6 szkół, 4 warsztaty i 4 kursy, z ogólną liczbą 411 uczących się ${ }^{15}$. Dzięki niezależności od władz polskich organizacja mogła pozwolić sobie na szeroką pomoc materialną dla swoich słuchaczy, a także na dużą swobodę w realizacji programu nauczania. Nic więc dziwnego, że cieszyła się dużą popularnością wśród społeczności żydowskiej, która mogła zdobyć przydatny w Izraelu zawód i jak najszybciej wyjechać z Polski ${ }^{16}$.

Od momentu powstania państwa Izrael 15 maja 1948 r. zdecydowanie zmienił się stosunek władz do mniejszości żydowskiej we wszystkich krajach tzw. demokracji ludowej, w tym również w Polsce. O ile mniejszość cieszyła się stosunkowo dużą swobodą i niezależnością swoich instytucji świeckich i religijnych (jak na warunki państwa totalitarnego), o tyle wkrótce pozbawiono ją tej autonomii. Latem 1948 r., na podstawie uprzedniej wizytacji inspektorów oświatowych we wszystkich szkołach, opracowano projekt przejęcia od roku szkolnego 1949/1950 szkół żydowskich przez państwo i likwidacji ośrodków, do których uczęszczała niewielka liczba uczniów. Znamienne, że upaństwowienie szkół miało dotyczyć tylko placówek pozostających pod auspicjami CKŻ $\mathrm{P}^{17}$. Już od września 1948 r. rozpoczęto zamykanie szkół hebrajskich i innych instytucji religijnych, a następnie zlikwidowano Wydział Emigracyjny CKŻP. Powstała w grudniu 1948 r. PZPR wchłonęła Powszechny Żydowski Związek Robotniczy (Bund ${ }^{18}$ ), którego ostatni zjazd odbył się 16 stycznia 1949 r. we Wrocławiu ${ }^{19}$. Właśnie w 1949 r. rozpoczął się kres autonomii żydowskiej w Polsce, co miało swoje odzwierciedlenie w wzmocnieniu pozycji działaczy komunistycznych w żydowskich organizacjach i ich stopniowym zatracaniu odrębności narodowej ${ }^{20}$. Od czerwca tego samego roku rozpoczął się też proces upaństwawiania instytucji żydowskich: od szkół, na kuchniach ludowych skończywszy, a 13 grudnia wydano okólnik nakazujący likwidację wszystkich żydowskich partii politycznych. W październiku 1950 r., w wyniku połączenia CKŻP i Żydowskiego Towarzystwa Kultury, powstało podporządkowane ściśle władzy Towarzystwo Społeczno-

14 S. Bronsztejn, op. cit., s. 267.

15 A. Goldsztejn, Produktywizacja ludności żydowskiej na Dolnym Ślasku w latach 1945-1948, w: K. Matwijowski (red.), Z dziejów ludności żydowskiej na Śląsu, Wrocław 1991, s. 131-132.

${ }^{16}$ K. Pudło, Wybrane problemy z organizacji życia zbiorowego ludności żydowskiej na Dolnym Ślasku, w: K. Matwijowski (red.), op. cit., s. 156-157.

17 B. Szaynok, Ludność żydowska..., s. 182-183.

${ }_{18}$ Bund - Powszechny Żydowski Związek Robotniczy na Litwie, w Polsce i Rosji - partia polityczna o programie socjalistycznym utworzona w 1897 r. w Wilnie. Bund opowiadał się za autonomią narodowo-kulturową ludności żydowskiej i uznaniu języka jidysz za narodowy, odrzucając jednocześnie syjonizm. W latach trzydziestych XX w. blisko współpracował z Polską Partią Socjalistyczną.

19 J. Szczeblewski, Kronika najważniejszych wydarzeń w Polsce Ludowej w latach 1944-1964, w: W. Góra, J. Gołębiowski (red.), Z dziejów Polski Ludowej, Warszawa 1966, s. 415.

${ }^{20}$ F. Nowak-Małolepsza, T. Włodarczyk, Żydzi, w: S. Dudra, B. Nitschke, Mniejszości narodowe i etniczne w Polsce po II wojnie światowej, Kraków 2010, s. 216. 
Kulturalne Żydów (TSKŻ) ${ }^{21}$. Tym samym została urzeczywistniona Decyzja o likwidacji instytucjonalnego separatyzmu żydowskiego w Polsce Ludowej ${ }^{22}$, co zdecydowanie przyczyniło się do wyjazdów Żydów z Polski. W wyniku emigracji w latach 1949-1950 Polskę opuściło ok. 30 tys. Żydów ${ }^{23}$, a w kraju pozostały już tylko osoby ściśle związane z Polską, które bardziej czuły się Polakami niż Żydami.

\section{Oświata w Legnicy}

Przedwojenna społeczność żydowska w Legnicy należała do elity kulturalnej i finansowej miasta. Już w 1814 r. przy ul. Rycerskiej powstała pierwsza w nowożytnej historii miasta szkoła żydowska i dom modlitwy. Wyznający judaizm obywatele miasta czuli się niejednokrotnie bardziej Niemcami aniżeli Żydami, z którymi łączyła ich w zasadzie tylko religia. Wielu spośród nich piastowało ważne funkcje w mieście - byli członkami zgromadzenia radnych miejskich, syndykami, członkami egzekutywy municypalnej, lekarzami, prawnikami etc. Pokojowe współistnienie obu narodów zostało brutalnie przerwane w 1933 r., gdy władza w Republice Weimarskiej zaczęła stopniowo przechodzić w ręce Adolfa Hitlera ${ }^{24}$. Pogarszający się niemal z dnia na dzień klimat wokół mniejszości żydowskiej na terenie III Rzeszy nie ominął również pótoratysięcznej społeczności w Legnicy, skąd rozpoczęły się jej masowe wyjazdy. W efekcie tzw. kryształowa noc ${ }^{25}$ zastała w mieście grupę liczącą już tylko od ok. 400 do 700 mieszkańców. W czasie antysemickich zajść nad ranem 10 listopada spłonęła synagoga, a wraz z nią cenne judaika; dotkliwie pobito Żydów, nierzadko w ich własnych mieszkaniach. Przestraszona społeczność opuszczała miasto w popłochu, zostało 66 osób zbyt chorych lub biednych, aby wyjechać i których los został przypieczętowany ${ }^{26}$.

W 1945 r. Legnica rozpoczęła kolejny ,żydowski etap” w swojej historii ${ }^{27}$. Już $\mathrm{w}$ pierwszej połowie tego roku pojawili się w mieście polscy osadnicy, a wraz z nimi Żydzi. Początkowo byli to przeważnie ocaleni więźniowie rozsianych po całym Dolnym

${ }^{21}$ M. Szydzisz Działalność dolnoślaskich oddziałów Towarzystwa Społeczno-Kulturalnego Żydów w Polsce w latach 1950-1989, w: E. Waszkiewicz (red.), op. cit., s. 72.

22 J. Orlicki, Szkice z dziejów stosunków polsko żydowskich 1918-1949, s. 234.

${ }^{23}$ H. Datner, M. Melchior, Żydzi we współczesnej Polsce - nieobecność i powroty, w: Z. Kurcz (red.), Mniejszości narodowe $w$ Polsce, Wrocław 1997, s. 73.

${ }^{24}$ W. Kalski, Liegnitz znaczy Legnica, Legnica 1997, s. 18.

${ }^{25}$ Kryształowa noc - nazwa nadana antysemickim rozruchom w III Rzeszy, do których pretekstem stało się zastrzelenie przez Herszla Gryszpana pracownika ambasady niemieckiej w Paryżu. W wyniku włamań, pobić i grabieży w nocy z 9 na 10 listopada 1938 r. rozpoczęły się masowe wyjazdy Żydów z obszaru III Rzeszy. Nazwa ekscesów została nadana na pamiątkę tłuczonego szkła w żydowskich oknach.

${ }^{26}$ P. Piluk, Chłód listopadowej nocy, „Wersja Legnicka” 1999, nr 11, s. 20-21.

${ }_{27}$ Wcześniej, w średniowieczu Żydzi mieszkali w mieście, a następnie zostali z niego wypędzeni. W $1812 \mathrm{r}$. król Fryderyk Wilhelm wydał Edykt o stosunkach obywatelskich (zwany Edyktem emancypacyjnym) nadający wszystkim Żydom w królestwie pruskim równouprawnienie, w tym wolność wykonywania zawodu, praktyk religijnych i swobodnego zamieszkania. Dzięki temu do Legnicy zaczęli napływać przedstawiciele tej mniejszości. 
Śląsku filii obozu koncentracyjnego Gross-Rosen ${ }^{28}$. W listopadzie przybył do Legnicy pierwszy transport żydowskich repatriantów, ocalonych na terenie ZSRR. Nowo przybyli szybko „zadomowili się” na legnickiej starówce, gdzie powstawały - zwłaszcza przy ulicy Grodzkiej - sklepiki i warsztaty rzemieślnicze. Nie zachowały się do dzisiaj żadne materiały z tamtych lat, wiadomo jedynie, że 11 grudnia 1945 r. w rodzinie Menachema i Marii Birenbaum przyszła na świat córka Raisa, co zostało zapisane w księdze stanu cywilnego 29 .

Rok 1946 wyłania się nieco z przeszłości za sprawą nielicznych ocalałych źródeł, a także wspomnień żyjących jeszcze świadków. Po raz pierwszy wzmianka o diasporze żydowskiej w Legnicy pojawiła się już w styczniu tego roku w ewidencji Wojewódzkiego Komitetu Żydowskiego w Dzierżoniowie. Odnotowano wówczas, że Lignicę (ówczesna nazwa miasta) zamieszkuje 470 przedstawicieli mniejszości, choć drugie tyle znajduje się poza statystykami instytucji ${ }^{30}$. Wraz z rozpoczęciem repatriacji z ZSRR wzrastała dynamicznie liczba przyjezdnych, dzięki czemu liczebność mniejszości żydowskiej na Dolnym Śląsku powiększyła się sześcio-, a w samej Legnicy pięciokrotnie ${ }^{31}$.

Dziś nie sposób ustalić jak liczna była ta społeczność w omawianym okresie, ponieważ zachowane źródła nie są jednomyślne. Bożena Szaynok po zbadaniu archiwów Wojewódzkiego Komitetu Żydowskiego i Żydowskiego Instytutu Historycznego zebrała dane dotyczące ludności żydowskiej w wielu miastach Dolnego Śląska, a w tym:

Tabela. Liczba ludności żydowskiej w miastach Dolnego Śląska

\begin{tabular}{|l|c|c|c|c|c|}
\hline \multicolumn{1}{|c|}{ Miasto } & Styczeń & Marzec & Maj & Czerwiec & Lipiec \\
\hline Legnica & 475 & 1055 & 2702 & 3550 & 4450 \\
\hline Chojnów & - & - & 522 & 1388 & 1754 \\
\hline Jawor & - & - & 558 & 656 & 1056 \\
\hline Złotoryja & - & - & 173 & 843 & 1073 \\
\hline
\end{tabular}

Źródło: B. Szaynok, Ludność żydowska..., s. 50-51.

Wraz osiedlaniem się nowych przedstawicieli mniejszości powstały i rozwijały się kolejne instytucje edukacyjne: dom dziecka, przedszkole, dwie szkoły podstawowe, cheder, placówka ORTu i kibuc.

Spośród żydowskich instytucji edukacyjnych w Legnicy najmniej wiemy dziś o działającym tu kibucu. Wiadomo jedynie, że mieścił się przy Placu Wolności i prawdopodob-

\footnotetext{
${ }^{28}$ P. Piluk, Jeszcze zbiera się minjan..., „Wersja Legnicka” 2001, nr 2/3, s. 20.

${ }_{29}$ P. Piluk, Żydzi w powojennej Legnicy, „Dos jidysze Wort” („Słowo Żydowskie”) 1997, nr 18, s. 20.

30 B. Szaynok, Ludność żydowska..., s. 27.

31 B. Szaynok, Odbudowa życia żydowskiego w Polsce po wojnie na przykładzie osadnictwa żydowskiego na Dolnym Ślqsku, w: J. Tomaszewski, J. Valent (red.), Żydzi w polskim i czeskim społeczeństwie obywatelskim, Praga 1999, s. 161-162.
} 
nie działał pod patronatem He-chaluc, ale jak długo funkcjonował - tego nie da się już ustalić $^{32}$.

Nieco więcej informacji, głównie dzięki relacjom ustnym, zachowało się natomiast o istniejącym w mieście domu dziecka. Jego obecność odnotowuje Bożena Szaynok, oceniając, że w grudniu 1947 r. przebywało w nim 70 dzieci33 w dwóch budynkach, a dzieci mieszkały w kamienicy przy zbiegu dzisiejszych ulic Piastowskiej i Senatorskiej (vis a vis obecnej SP nr 4). Tu również rozlokowano magazyny, natomiast administracja oraz grupa młodszych dzieci przebywała w domu przy ulicy Piastowskiej, dzisiejszej siedzibie Ligi Obrony Kraju. Na co dzień używano języka polskiego, choć czasem istniała konieczność posługiwania się także rosyjskim, ze względu na wychowanków urodzonych w ZSRR. Placówka miała charakter świecki (pracowano również w sobotę) i chociaż organizowano święta Chanuka i Purim, jednocześnie obecna była choinka, zabawy Sylwestrowe i Nowy Rok. Ośrodek zamknięto na początku lat pięćdziesiątych, przenosząc dzieci do innych placówek ${ }^{34}$.

Kolejną instytucją zajmującą się opieką nad dzieckiem żydowskim, było położone przy ulicy Złotogórskiej 56 (dzisiejsza ulica Złotoryjska) Przedszkole im. J. L. Korczaka. Z zachowanego formularza statystycznego z dnia 10 października 1948 r. wynika, że właścicielem placówki był CKŻP w Warszawie, którego subsydia stanowiły źródło utrzymania przedszkola. W opisywanym okresie uczęszczało tu 92 dzieci podzielonych na cztery grupy. Placówką kierowała Karolina Barszon, a oprócz niej personel dydaktyczny stanowiły cztery wychowawczynie ${ }^{35}$. Z kolejnego sprawozdania za lata 1946-1949 dowiadujemy się ponadto, że w wynajmowanym od Zarządu Miejskiego budynku oprócz przedszkola działał również półinternat, a obie placówki grupowały łącznie 94 osoby. W dokumencie odnotowano również zły stan trzykondygnacyjnej i zniszczonej w 40\% kamienicy, pozbawionej centralnego ogrzewania i gazu ${ }^{36}$.

$\mathrm{Na}$ terenie Legnicy działały dwie żydowskie szkoły podstawowe - objęta patronatem CKŻP Szkoła Powszechna im. J. L. Pereca i pozostająca pod auspicjami He-chaluc siedmioklasowa Szkoła Hebrajska im. Ch. N. Bialika, a także otoczona opieką kongregacji elementarna szkoła religijna przeznaczona dla młodszych uczniów (cheder). Pierwsza wzmianka o placówce, działającej przy komitecie, pochodzi z listopada 1946 r., kiedy pełniący obowiązki dyrektora szkoły (nieczytelny podpis) zawiadamia, że do jego ośrodka uczęszcza 136 dzieci37. Natomiast o ośrodku podlegającym He-chaluc zachowała się informacja kierownika Berg Wolfa z dnia 26 kwietnia 1947 r. o przeniesieniu szkoły

\footnotetext{
32 Relacja ustna Jankiela Kulawca (nagranie w posiadaniu autora).

33 B. Szaynok, Ludność żydowska..., s. 126.

${ }^{34}$ Relacja ustna Marty Szkołt (nagranie w posiadaniu autora).

${ }^{35}$ Formularz statystyczny dla przedszkola na rok szkolny 1948-1949. APL [Archiwum Państwowe we Wrocławiu. Oddział w Legnicy], ZM [ Zarząd Miejski w Legnicy], sygn. 237, s. 189-190.

${ }^{36}$ Karta inwentaryzacyjna na dzień 1.XI.1948 r. Przedszkola im. Janusza Korczaka przy Komitecie Żydowskim w Legnicy, APL, ZM, sygn. 237, s. 118-119.

37 Wykaz uczniów i uczennic Pólinternatowej Szkoły Powszechnej przy Komitecie Żydowskim w Legnicy ul. Muzealna 2, za listopad 1946 z dnia 19.11.1946. APL, ZM, sygn. 223, s. 2.
} 
z budynku przy Placu Wolności 6 do lokalu przy ulicy Chojnowskiej $46^{38}$. Kolejnym ustalonym faktem dotyczącym Szkoły Powszechnej im. Pereca jest odmowa udzielenia jej dotacji przez Inspektorat Szkolny, gdyż jako instytucja prywatna nie podlegała starostwu, natomiast pismo z 28 maja 1947 r. zawiadamiało o nowej siedzibie instytucji przy ulicy Chojnowskiej $46^{39}$. Z przeprowadzonych przeze mnie rozmów z dawnymi uczniami tej szkoły okazuje się, że placówka ta nigdy nie mieściła się przy ulicy Chojnowskiej, możliwa jest zatem pomyłka starostwa, które podało adres szkoły hebrajskiej.

Bardziej szczegółowe są informacje z nieco późniejszego okresu, tj. z września 1947 r. Położona przy ulicy Rycerskiej 13 szkoła im. J. L. Pereca zatrudniała wówczas 11 nauczycieli, w tym 8 wykwalifikowanych, obowiązkiem nauczania obejmując 219 dzieci urodzonych w latach 1931-1939, podzielonych na siedem klas ${ }^{40}$. Program szkoły nie odbiegał zasadniczo od publicznych szkół podstawowych, większość przedmiotów była wspólna, za wyjątkiem języka żydowskiego (jidysz), historii Żydów i języka hebrajskiego (uczono go od czwartej klasy) ${ }^{41}$. W roku następnym kierowana przez Bena Rachwalskiego wszechnica liczyła już 289 uczniów i 13 nauczycieli, ośrodek posiadał również własną salę gimnastyczną i bibliotekę z 912 tomami ${ }^{42}$.

W analogicznym czasie działało szkolnictwo wyznaniowe i syjonistyczne - mieszczący się w siedzibie kongregacji cheder przy ulicy Grodzkiej 20/21 i placówka przy Chojnowskiej 46. Pierwsza z wymienionych instytucji obejmowała edukacją 36 dzieci w dwóch klasach (I i II) oraz zatrudniała troje nauczycieli. Uczono języka hebrajskiego, polskiego, matematyki, rysunku, śpiewu i wychowania fizycznego, a po ukończeniu chederu uczniowie trafiali do szkoły żydowskiej, polskiej lub hebrajskiej ${ }^{43}$. Ostatnia znacznie ustępowała swym standardem pozostałym, gdyż oprócz centralnego ogrzewania brakowało tu pomocy szkolnych, ławek i książek. Pod koniec 1947 r. uczęszczało do niej 68 dzieci otoczonych opieką przez siedmiu nauczycieli, ale liczby te ulegały ciagłym zmianom z powodu wyjazdu z Polski religijnych Żydów. W programie nauczania oprócz Biblii, języka hebrajskiego, żydowskiego, historii Żydów i geografii Palestyny wykładano te same przedmioty jak w placówkach publicznych. ${ }^{44}$.

W marcu 1949 r. rozpoczęły się kontrole podinspektora szkolnego mgr. Apolinarego Słupskiego w legnickich szkołach. Według wizytatora podlegający komitetowi ośrodek prowadzony był zarówno pod względem dydaktycznym, administracyjnym, jak i higie-

\footnotetext{
${ }^{38}$ Pismo kierownika szkoły hebrajskiej do Inspektoratu Szkolnego w Legnicy z dnia 16 kwietnia $1947 \mathrm{r}$. APL, ZM, sygn. 223, s. 3-4.

39 Pismo inspektora szkolnego do Kierownictwa Szkoły przy Komitecie Żydowskim w Legnicy, ul. Chojnowska 46, APL, ZM, sygn. 223, s. 5.

${ }^{40}$ Pismo kierownika szkoły przy Komitecie Żydowskim do inspektora szkolnego w Legnicy. APL, ZM, sygn. 223, s. 6-7; Wykaz dzieci w wieku obowiazku szkolnego zamieszkatych $w$ obwodzie danej szkoty wg stanu z dnia 10.09.1947 r., op. cit., s. 8.

${ }^{41}$ Formularz sprawozdawczo-statystyczny dla szkół powszechnych na rok szkolny 1947-1948, APL, ZM, sygn. 223, s. 9-16.

42 Ibidem, s. 35-38.

43 Ibidem, s. 25-32.

44 Ibidem, s. 17-24.
} 
nicznym należycie. Poziom nauczania stał na bardzo wysokim poziomie, podobnie jak kultura osobista i dyscyplina 293 uczniów. Autor z satysfakcją podkreśla istnienie czterech drużyn zuchów i harcerzy, Towarzystwa Przyjaciół Żołnierzy i Towarzystwa Przyjaźni Polsko-Radzieckiej ${ }^{45}$. Odmienny obraz wyłania się po lekturze protokołu z kontroli szkoły hebrajskiej, umieszczonej w zniszczonej i nieprzystosowanej do celów dydaktycznych kamienicy. Słupski wskazuje, że 85 uczęszczających uczniów nie ma ani pomocy naukowych, ani książek. Brakuje także opracowanych programów nauczania, nie ma obliczonej frekwencji, nie prowadzi się hospitacji klas, w dziennikach są puste strony ${ }^{46}$. Zdecydowanie najgorzej wypadł w trakcie kontroli prowadzony przez Zofię Szwarcberg cheder. Brak sal (kongregacja udostępniła jeden pokój) zmuszał dzieci do uczęszczania na odbywające się zajęcia w różnych godzinach. Zdaniem Słupskiego kierowniczka szkoły nie nadaje się do zawodu, gdyż brak jakichkolwiek dokumentów potwierdzających jej przygotowanie pedagogiczne ${ }^{47}$. W efekcie podinspektor wniósł o natychmiastowe zamknięcie chederu i przeniesienie dzieci do innych szkół oraz likwidację z końcem roku szkolnego 1948/1949 prywatnej szkoły hebrajskiej im. CH. N. Bialika. Postulował, aby inwentarz placówki i kwalifikowanych nauczycieli przenieść do upaństwowionej szkoły publicznej im. J. L. Pereca ${ }^{48}$. Proponowane przez Apolinarego Słupskiego zmiany zostały zaakceptowane, co dokumentuje zgoda Kuratorium Szkolnego Wrocławskiego z dnia 27 kwietnia 1949 r. na utworzenie w Legnicy szkoły publicznej z żydowskim językiem nauczania ${ }^{49}$.

Obok opisywanych wyżej instytucji w Legnicy istniał także oddział ORTu, powstały stosunkowo późno, gdyż pierwsze informacje o jego działalności pochodzą dopiero z lipca 1947 r. Odnotowano wówczas dwie placówki z 36 uczniami, ale rok później w sześciu placówkach na kursach kształciło się 113 słuchaczy $^{50}$.

\section{Sytuacja Żydów w latach 1950-1968}

Druga połowa lat pięćdziesiątych ubiegłego stulecia przyniosła nasilające się walki wewnątrz PZPR i budzenie się drzemiących w społeczeństwie nastrojów antyżydowskich. Apogeum nastapiło podczas obrad VII Plenum PZPR w dniach 18-28 VII 1956 r., kiedy ówczesny członek Biura Politycznego PZPR Zenon Nowak przedstawił referat, w którym wprawdzie odżegnywał się od antysemityzmu, ale przedstawił dane statystyczne, odnoszące się do obsady przez Żydów kluczowych stanowisk, żądając jednocześnie

${ }^{4}$ Sprawozdanie powizytacyjne $z$ wizytacji $w$ żydowskiej szkole powszechnej im. Pereca $w$ Legnicy $\mathrm{z}$ dnia 19 marca 1949 r., APL, ZM, sygn. 223, s. 66-67.

46 Sprawozdanie z wizytacji szkoły hebrajskiej im. Ch. N. Bialika w Legnicy, APL, ZM, sygn. 223, s. 58.

47 Sprawozdanie z wizytacji szkoły żydowskiej „Cheder” w Legnicy, APL, ZM, sygn. 223, s. 59.

${ }^{48}$ Pismo podinspektora szkolnego Apolinarego Słupskiego do Kuratorium Okręgu Szkolnego Wrocławskiego. APL, ZM, sygn. 223, s. 63.

49 Pismo Kuratorium Okręgu Szkolnego Wrocławskiego do Inspektoratu Szkolnego w Legnicy z dnia 27 kwietnia 1949 r. APL, ZM, sygn. 223, s. 75.

${ }^{50}$ B. Szaynok, Ludność żydowska..., s. 115. 
uregulowania spraw kadrowych w oparciu o narodowe kryteria. Oznaczało to czystki w aparacie partyjnym i próbę zrzucenia na Żydów całej odpowiedzialności za stalinizm, uosabiany przez Jakuba Bermana i Hilarego Minca. W efekcie ożywiły się wyjazdy Żydów, co obrazuje fakt, iż druga po Polakach grupą wyjeżdżająca z państwa rekrutowała się właśnie z przedstawicieli tej mniejszości. Jednocześnie od 1957 r. rozpoczęły przyjazdy przedwojennych obywateli Polski z głębi ZSRR, wśród których obecni byli również Żydzi. Tym samym liczba 30 tys. przedstawicieli tej społeczności zamieszkujących Dolny Śląsk w połowie lat pięćdziesiątych została powiększona o ok. 13 tys. ich rodaków, z których jednak ok. 60\% wyjechało wkrótce z kraju ${ }^{51}$ (przyjezdni obok Świdnicy, Wałbrzycha i Dzierżoniowa wybierali także Legnicę jako miejsce osiedlenia, co sprawiło, że w 1959 r. istniało tu najliczniejsze skupisko Żydów na Dolnym Śląsku - 3500 osób $^{52}$ ). W latach 1957-1960 opuściło Polskę ok. 30 tys. osób i taka sama liczba pozostała w kraju (w tym 7-8 tys. na Dolnym Śląsku ${ }^{53}$ ). Chociaż z dawnej autonomii nic nie pozostało, to w ograniczonym zakresie po odwilży popaździernikowej odrodziło się życie społeczne. Czołową rolę odegrało tu TSKŻ koordynujące życie kulturalne (wydatnie podtrzymujące, zwłaszcza na prowincji, świadomość narodową) i oświatowe - działało wówczas dziewięć szkół z ogólną liczbą ok. 1200 dzieci54 ${ }^{54}$

Dekadę po Październiku w Polsce postępował kryzys ekonomiczny, w którego społeczeństwo stawało się biedniejsze, półki sklepowe puste, zaostrzały się antydemokratyczne rozwiązania władz (dawno już cofnięto namiastki popaździernikowych wolności). Rok 1967 przyniósł zerwanie stosunków dyplomatycznych PRL z Izraelem, który w tzw. wojnie sześciodniowej ${ }^{55}$ - rozgromił siły arabskie. I chociaż Izrael stał się obiektem zmasowanych ataków propagandowych w polskich mediach, co przełożyło się m.in. na skandaliczny stosunek urzędników lotniska i służby celnej wobec opuszczających Polskę pracowników ambasady państwa żydowskiego, to jednak nieoficjalnie odnotowywano wzrost sympatii społeczeństwa wobec tego państwa ${ }^{56}$. Jednocześnie w szeregach partii rosła w siłę grupa skupiona wokół gen. Mieczysława Moczara (tzw. partyzanci), która głosząc hasła ksenofobiczne i narodowe dążyła do przejęcia władzy i odsunięcia dotychczasowego kierownictwa w państwie ${ }^{57}$.

W styczniu 1968 r. rozpoczęła się ,praska wiosna"58, a całość dopełniły manifestacje studenckie wywołane zdjęciem z afisza „Dziadów” w reżyserii Kazimierza Dejmka. Wła-

51 E. Waszkiewicz, op. cit., s. 26-27.

52 M. Szydzisz, op. cit., s. 84-85.

53 E. Waszkiewicz, op. cit., s. 28.

54 H. Datner, M. Melchior, op. cit., s. 74-75.

$55 \mathrm{~W}$ dniach 5-10 czerwca 1967 r. wojska izraelskie rozgromiły szykujące się do inwazji armie Egiptu, Syrii i Jordanii.

${ }^{56}$ B. Szaynok Polska i Izrael w czasie rzqdów Gomulki 1956-1970, w: K. Ruchniewicz, B. Szaynok, J. Tyszkiewicz (red.), Między październikiem a grudniem. Polityka zagraniczna doby Gomótki, Toruń 2005, s. 78-79.

57 E. Waszkiewicz, op. cit., s. 29.

58 „Praska wiosna” - określenie procesu politycznego w Czechosłowacji liberalizującego komunistyczny reżim, zapoczątkowany 5 stycznia 1968 wyborem Aleksandra Dubczeka na stanowisko I sekretarza Komuni- 
dze postanowiły zatem szybko znaleźć winnego niepokojów społecznych i całą winą za sytuację obarczono syjonistów ${ }^{59} .11$ marca 1968 r. „Trybuna Ludu” opublikowała artykuł sugerujący, że inspiratorami zajść studenckich były osoby pochodzenia żydowskiego, dzieci wysokich urzędników państwowych. Po niej antysemicką nagonkę pod hasłami walki z syjonizmem przeprowadzały inne, poddane ścisłej kontroli media. Apogeum wrogości na linii władza - studenci nastappiło 14 marca, kiedy I sekretarz KC PZPR Władysław Gomułka w swoim przemówieniu wygłoszonym w Katowicach groził „wrogom ludu”, ,wichrzycielom”, ,syjonistom” i innym wrogom ,pogruchotaniem kości”. Wystąpienie towarzysza „Wiesława” (taki pseudonim w czasie wojny nosił Gomułka) wywołało kolejne strajki i dopiero groźba likwidacji uczelni i rozpisania rekrutacji od nowa skłoniła studentów do zaniechania protestów ${ }^{60}$. W całym kraju przeprowadzano „,spontaniczne” demonstracje i aranżowane odgórnie „masówki”, na których domagano się usunięcia syjonistów zarówno z szeregów partii, jak i całego życia społeczno-gospodarczego PRL.

Wydarzenia marcowe ostatecznie pogrzebały nadzieje Żydów na normalne funkcjonowanie w ramach wspólnego państwa polskiego. Pisze o tym Bożena Szaynok: Sytuacja polityczna w Polsce, zawirowania wokót problematyki żydowskiej były przyczyna emigracji ludności żydowskiej z Polski i Polaków żydowskiego pochodzenia ${ }^{61}$. Nieliczna grupa, która oparła się falom wyjazdów z lat 1946-1950 i 1956-1960 i pozostała w PRL, gdyż czuła się Polakami, zrozumiała, że w tym państwie nie ma dla nich miejsca. W wyniku tzw. wydarzeń marcowych Polskę opuściło ok. 20 tys. obywateli pochodzenia żydowskiego, często całkowicie zasymilowanych. Tym samym przestało istnieć instytucjonalne życie żydowskie ${ }^{62}$.

\section{Oświata w Legnicy}

Początek lat pięćdziesiątych przyniósł likwidację żydowskiego domu dziecka przy ulicy Senatorskiej $7^{63}$. Prawdopodobnie jego ostatnim lub jednym z ostatnich kierowników był wówczas Alter ${ }^{64}$, ale w ostatniej informacji o placówce, do której dotarłem, dotyczącej przygotowania ośrodka do roku szkolnego 1950/51, nie figuruje żadne nazwisko ${ }^{65}$.

\footnotetext{
stycznej Partii Czechosłowacji i zakończony 20 sierpnia 1968 r. inwazją wojsk Układu Warszawskiego na Czechosłowację.

59 Syjonizm - ruch polityczny stawiający sobie za cel powstanie państwa Izrael, a od 1948 r. - imigracji do niego Żydów z całego świata.

${ }^{60}$ W. Roszkowski, Historia Polski 1914-2000, Warszawa 2001, s. 289-291.

${ }^{61}$ B. Szaynok Z historiq i Moskwq w tle. Polska a Izrael 1944-1968, Warszawa 2007, s. 452.

${ }^{62}$ H. Datner, M. Melchior, op. cit., s. 75.

${ }^{63}$ Wykaz czynnych świetlic młodzieżowych i dziecięcych na terenie Legnicy z dnia 03.05.1950 r., APL, Prezydium Miejskiej Rady Narodowej [PMRN], sygn. 510, s. 129.

${ }^{64}$ Relacja ustna Jankiela Kulawca (nagranie w posiadaniu autora).

${ }^{65}$ Rola poszczególnych placówek wychowawczo-opiekuńczych - referat na Konferencję Sierpniowa 1950 roku. APL, Prezydium Powiatowej Rady Narodowej, sygn. 902, s. 6.
} 
Odmienny los czekał przedszkole, które jako Przedszkole Nr 5 im. Janusza Korczaka podlegało Wydziałowi Oświaty Prezydium Miejskiej Rady Narodowej (PMRN) i przez kolejnych kilka lat zachowało swój żydowski charakter. Kierowała nim nadal Karolina Barszon, a oprócz niej zatrudniono cztery wychowawczynie i jedenaścioro pracowników administracyjno-gospodarczych. W roku 1950/51 uczęszczało do niego 138 dzieci66. Karolina Barszon cieszyła się dużym autorytetem wśród podległego personelu i urzędników miejskich. Przedszkole bogato wyposażono w pomoce naukowe ${ }^{67}$, zadbano także o odpowiednie przeszkolenie ideologiczne podległych pracowników ${ }^{68}$, a także dzieci69. Była to bardzo popularna placówka w mieście, o czym świadczą skargi matek nieprzyjętych tu dzieci $^{70}$, a także donos do KM PZPR Michała Chmiela - ojca dziecka narodowości polskiej, które również nie zostało przyjęte ze względu na brak wolnych miejsc ${ }^{71}$. Podobne „,interwencje” nie przynosiły jednak zamierzonych efektów i do 1955 r. przedszkole działało bez zakłóceń. W tym roku funkcję kierownika pełniła już Berman, a w piśmie PPRN z dnia 9 kwietnia 1955 r. do Wojewódzkiego Związku Spółdzielni Pracy we Wrocławiu proponuje się przejęcie od 1 września 1955 r. przez WZSP Przedszkola Nr 5 jako jednego z najlepszych w mieście ${ }^{72}$. W późniejszych dokumentach Przedszkole Nr 5 położone przy ulicy Złotoryjskiej figuruje jako Przedszkole $\mathrm{Nr} 1$.

W lata pięćdziesiąte XX w. dotychczasowa szkoła podstawowa przy ul. Róży Luksemburg $13^{73}$ objęta patronatem CKŻP weszła jako Szkoła Podstawowa Nr 7 im. J. L. Pereca. Kierownikiem placówki liczącej w czerwcu 1950 r. 324 uczniów, był Beno Rachwalski (od 1951 r. Zygmunt Steiner), a grono pedagogiczne składało się z dziewięciu nauczycieli. W szkole działały wówczas Związek Harcerstwa Polskiego (należało 220 uczniów), Związek Młodzieży Polskiej, Koło Odbudowy Warszawy, Koło Obrońców Pokoju i Towarzystwo Przyjaźni Polsko-Radzieckiej ${ }^{74}$. Obchodzono hucznie rocznice Rewolucji Październikowej, Dni Ludowego Wojska Polskiego, Święta Pokoju itd.

W kolejnych latach ogólna liczba uczniów i nauczycieli zmieniała się w niewielkim stopniu, chociaż wyraźne były liczne rotacje osobowe. W efekcie brakowało nauczycieli

\footnotetext{
${ }^{66}$ Formularz sprawozdawczo-statystyczny na rok szkolny 1950/51 dla przedszkola, APL, PMRN, sygn. 484, s. 5 .

${ }^{67}$ Pismo PMRN do Wojewódzkiej Rady Narodowej we Wrocławiu dot. przedszkoli w Legnicy, APL, PMRN, sygn. 484, s. 33-34.

${ }^{68}$ Analiza wyników pracy za I pótrocze 1952/53 w przedszkolach na terenie miasta Legnicy, APL, PMRN, sygn. 484 , s. 162.

${ }^{69}$ Sprawozdanie ze stanu wychowawczego i sanitarnego $w$ b. r. szkolnym $w$ Przedszkolu Nr 5 w Legnicy. APL, PMRN, sygn. 484, s. 191.

70 Protokót z przeprowadzonej kontroli w Przedszkolu $N r 5 w$ dniu 03 września 1953 r., APL, PMRN, sygn. 106, s. 47.

71 Zażalenie Michała Chmiela skierowane do PMRN w Legnicy z 19.08.1953 r. na pracę kierowniczki Przedszkola Nr 5, APL, PMRN, sygn. 106, s. 49.

72 AP, PMRN, sygn. 106, s. 258.

73 Nazwa ta została nadana obecnej ul. Rycerskiej w 1952 r.

74 Sprawozdanie roczne szkoły z żydowskim językiem nauczania z dnia 26.06.1950 r. APL, PPRN, sygn. 987, s. $1-7$.
} 
władających biegle językiem żydowskim i potrafiących prowadzić w nim zajęcia. Coraz częściej pracowali tu, a nawet uczyli się Polacy nieznający tego języka. Dlatego też od 1 września 1953 r. oficjalnie wprowadzono język polski jako wykładowy, a żydowski pozostał jedynie jako jeden z nauczanych przedmiotów ${ }^{75}$. W roku w 1956 r. odszedł Steiner, który został powołany na stanowisko Przewodniczącego Miejskiej Komisji Planowania Gospodarczego ${ }^{76}$, a jego następcą w roku szkolnym 1956/57 został Aron Siano, a następnie decydujący się wkrótce na emigrację ${ }^{77}$. Jego funkcję objęła Rachela Lanajl, która z uwagi na malejącą liczbę Żydów w mieście, przyjęła do szkoły dzieci greckie i macedońskie ${ }^{78}$. Po pierwszym półroczu roku 1956/57 na ogólną liczbę 342 uczniów aż 35 stanowiły dzieci greckie ${ }^{79}$.

Nowy okres w historii Szkoły Podstawowej Nr 7 wiąże się z masowym przyjazdem Żydów do Legnicy po 1956 r., a w ślad za tym ze zwiększeniem liczby uczniów w placówce. Ponieważ stan techniczny budynku przy ul. Róży Luksemburg 13 nie pozwalał na jego dalsze użytkowanie bez kapitalnego remontu, postanowiono przenieść szkołę do innego budynku. Nie bez znaczenia był tu również fakt, iż spodziewano się dużo większej liczby uczniów, których nie pomieściłby stary gmach. Dlatego od roku szkolnego 1957/58 szkoła zaczęła funkcjonować w nowym obiekcie przy ul. Rewolucji Październikowej $32^{80}$. W maju 1958 r. liczba uczniów wynosiła już 508 i oceniano, że we wrześniu wzrośnie do 563. Prawdopodobnie dzieci greckie i macedońskie przeniesiono do innych placówek, ponieważ w programie szkoły nie widniała już nauka tych języków, znikły też nazwiska uczących je nauczycieli. Grono pedagogiczne liczyło 20 osób pod kierownictwem Szymona Holcblata ${ }^{81}$, który najprawdopodobniej zastąpił na tym stanowisku Cylę Szerman $^{82}$. Od września 1958 r. uczyło się w placówce 608 uczniów, a pod koniec roku szkolnego już 757. Jednocześnie widoczna była niestabilność kadr: w ciagu roku zmieniło się siedmioro nauczycieli, a kierownik Holcblat, podobnie jak troje jego poprzedników (Siano, Lanajl, Szerman) swą funkcję sprawował krótko i już 22 maja 1959 r. przekazał ją Mendlowi Tannenzapfowi ${ }^{83}$. s. 216.

${ }^{75}$ Sprawozdanie z zakresu szkolnictwa podstawowego na dzień 31.12.1953 r. APL, PPRN, sygn. 904,

${ }^{76}$ Uchwała Nr. 7/I/56 Sesji Miejskiej Rady Narodowej w Legnicy, odbytej w dniu 25 stycznia 1956 r. APL, PMRN, sygn. 8, s. 20.

77 Wspomnienia Szymona Fisha (tekst w posiadaniu autora).

${ }^{78}$ Projekt organizacji Szkoly Podstawowej Nr 7 w Legnicy na rok szk. 1956/57, APL, PPRN, sygn. 987, s. $85-86$.

${ }^{79}$ Arkusz sprawozdawczy z wyników klasyfikacji uczniów szkoły Nr 7 za I okres roku szkolnego 1956/57, APL, PPRN, sygn. 987, s. 95-96.

${ }^{80}$ Do 1952 r. funkcjonowała jako ul. Senatorska i do tej nazwy powrócono w $1991 \mathrm{r}$. S. $98-99$

${ }^{81}$ Projekt organizacji Szkoly Podstawowej Nr 7 w Legnicy na rok szk. 1958/59. APL, PPRN, sygn. 987,

${ }^{82}$ Projekt organizacji Szkoty Podstawowej Nr 7 w Legnicy na rok szk. 1957/58. APL, PPRN, sygn. 987, s. $104-106$.

${ }^{83}$ Protokót zdawczo-odbiorczy 1959 r., APL, PPRN, sygn. 987, s. 113. 
1 września 1959 r. przy szkole utworzono klasę licealną i od tego momentu palcówka nosiła nazwę Szkoła Podstawowa i Liceum Ogólnokształcące Nr III im. Janusza Korczaka. Naukę w placówce rozpoczęło 787 uczniów SP i LO, ale już pod koniec roku liczba ta spadła do 483. Chociaż przybyło do niej 26 osób, z Legnicy wyjechało 330 uczniów ${ }^{84}$. W roku następnym do III LO włączono klasę z językiem ukraińskim, której zajęcia odbywały się w budynku przy ulicy Chojnowskiej 100. Wprawdzie we wrześniu 1960 r. klasa liczyła tylko 22 uczniów, ale już w roku szkolnym 1961/1962 grupowała 100 uczniów $^{85}$. Od 1 września 1963 r. III LO zostało podzielone na dwie placówki: LO nr III z językiem żydowskim pod dyrekcją Mendla Tannenzapfa i ukraińskie LO nr IV pod dyrekcją dotychczasowej nauczycielki III LO Smilin ${ }^{86}$.

Lata sześćdziesiąte XX w. przyniosły zmniejszanie się liczby uczniów w szkole podstawowej i liceum. Sytuacja ta skłoniła władze do uruchomienia w ośrodku Liceum Medycznego, którego kadrę stanowić mieli nauczyciele z III LO ${ }^{87}$. W listopadzie $1964 \mathrm{r}$. w Szkole Podstawowej uczyło się 80 dzieci (w tym w klasach VIII-XI - 59) ${ }^{88}$, a w styczniu 1966 r. odpowiednio 59 i 42 (w tym ani jedno w klasie I), choć w szkole pracowało aż 11 nauczycieli (większość nie w pełnym wymiarze godzin) ${ }^{89}$. Mimo że w roku 1966/1967 przewidywano, że klasy I i II nie będą miały uczniów, a III-VII tylko 55, dyrektor uzyskał zgodę z Prezydium Wojewódzkiej Rady Narodowej we Wrocławiu na prowadzenie szkoły o czterech nauczycielach oraz dodatkowe godziny na język żydowski i historię Żydów ${ }^{90}$.

\section{Zakończenie}

Atmosfera ,przedmarcowa” dotarła również do Legnicy, gdzie w czerwcu 1967 r. pobity został mieszkaniec miasta z powodu swojej przynależności narodowej, a ujęty sprawca miał tłumaczyć swoje postępowanie społecznym przyzwoleniem na takie zachowanie $^{91}$. Również w tym samym roku czystki personalne miały miejsce w wojsku, dotykając szczególnie pion polityczny w Centralnym Ośrodku Szkolenia Wojsk Łączności.

\footnotetext{
${ }^{84}$ Ruch uczniów $i$ wyniki klasyfikacji w roku szk. 1959/60 oraz oddziały, APL, PPRN, sygn. 987, s. 128, Sprawozdanie z wyników nauczania $i$ wychowania za rok szk. 1959/60 w Szkole Podstawowej Nr 7 i III LO w Legnicy APL, PPRN, op. cit., s. 130.

${ }^{85}$ A. Bojakowski, Oświata i kultura w latach 1945-1989, w: S. Dąbrowski (red.), Legnica. Zarys monografii miasta, Wrocław-Legnica 1998, s. 519.

${ }^{86}$ Informacja o przygotowaniach do nowego roku szkolnego 1962/63. APL, PPRN, sygn. 913, s. 183.

87 Sprawozdanie kontroli Liceum Medycznego Pielegniarstwa przeprowadzonej dnia 18 kwietnia 1964 r. w Legnicy. APL, PPRN, sygn. 987, s. 244.

${ }^{88}$ Arkusz sprawozdawczy wyników klasyfikacji uczniów za I okres roku szkolnego 1964/65. APL, PPRN, sygn. 987, s. 283.

${ }^{89}$ Projekt organizacji Szkoly Podstawowej Nr 7 im. J. Korczaka w Legnicy na rok szk. 1967/68. APL, PPRN, sygn. 987, s. 307-310.

${ }^{90}$ Op. cit., s. 334.

91 M. Szydzisz, op. cit., s. 94.
} 
Kilka miesięcy później, na kanwie manifestacji studenckich w całym kraju, także i w Legnicy w dniach 15-17 marca doszło do manifestacji młodzieżowych, w których uczestniczyli studenci Studium Nauczycielskiego i młodzież szkolna ${ }^{92}$. W efekcie zajść przez legnickie zakłady pracy przetoczyły się manifestacje żądające ukarania winnych, zdemaskowania syjonistów i poparcia dla linii partii. Chociaż miejscowy TSKŻ szybko poparł działania władz i potępił syjonistów, podobnie jak żydowska załoga Spółdzielni „Postęp ${ }^{93 ",}$, nie uchroniło to mniejszości od ogólnokrajowego trendu zmian. Pracę straciło wielu legniczan pochodzenia żydowskiego, m.in. sekretarz PMRN Ignacy Pressler, prokurator Eliasz Feldman, kierownik III LO Mendel Tannenzapf i nauczyciel tej szkoły Jakub Szczupak ${ }^{94}$. Warto jednocześnie zwrócić uwagę na fakt, że odnotowano w tym czasie próby szykanowania dzieci z żydowskiego liceum, co skłoniło MO do zwiększenia patroli wokół szkoły ${ }^{95}$.

Dopełnieniem atmosfery ,pomarcowej” stało się zamknięcie z dniem 31 sierpnia 1968 r. III LO i SP Nr 7, które ze względu na zbyt małą liczbę uczniów (łącznie 38 dzieci) nie mogły funkcjonować jako samodzielne placówki ${ }^{96}$. Tym samym przerwana została ponad dwudziestoletnia historia żydowskiej oświaty w powojennej Legnicy.

Przedstawiając problem edukacji dzieci i młodzieży żydowskiej w Legnicy, nie sposób pominąć faktu, że w omawianym okresie część z nich uczęszczała do szkół polskich. Na podstawie przeprowadzonych przeze mnie rozmów z żyjącymi jeszcze świadkami tamtych lat mogę stwierdzić, że niektórzy rodzice nie chcieli, aby ich dzieci identyfikowano ze społecznością żydowską. Inni brali pod uwagę wyższy poziom polskich placówek (dotyczyło to zwłaszcza I i II Liceum Ogólnokształcącego), a jeszcze inni kierowali się osobistymi uprzedzeniami wobec Mendla Tannenzapfa ${ }^{97}$.

${ }^{92}$ Cz. Kowalak, Marzec '68 w Legnicy, T. Rollauer (red.), „Szkice legnickie” 2002, T. XXIII, Legnica 2002, s. 139-143.

93 Spółdzielnia wielobranżowa, która powstała w latach pięćdziesiątych XX w., produkująca słodycze i macę. Obok niej funkcjonowały m.in. spółdzielnie: obuwnicze i cholewkarskie („Dobrobyt” i „Przyszłość”), krawieckie (,Jedność” i „Igła”) i odzieżowe („Model” i „,im. Rosenbergów”).

94 Sprawozdanie z zakresu spraw narodowościowych za rok 1968, APL, PMRN, sygn. 549, s. 8-10.

95 M. Szydzisz, op. cit., s. 94.

96 Pismo PPRN w Legnicy do Prezydium Wojewódzkiej Rady Narodowej [PWRN] we Wrocławiu ws. SP 7 i III LO, APL, PPRN, sygn. 987, s. 336-337.

${ }_{97}$ Wspomnienia Adolfa Scharfa zamieszczone na http://webnews.textalk.com/plotkies, relacje ustne Marty Szkołt, Mojżesza Sznejsera i Heni Szklar (nagrania w posiadaniu autora). 
